November 1999 • NREL/CP-520-25783

\title{
Optical Modeling of a-Si Solar Cells
}

B. Sopori, J. Madjdpour, Y. Zhang, and W. Chen National Renewable Energy Laboratory

S. Guha, J. Yang, and A. Banerjee

United Solar Systems Corp.

S. Hegedus

Institute of Energy Conversion

Presented at the Materials Research Society's

Spring '99 Meeting

San Francisco, California

April 5-9, 1999

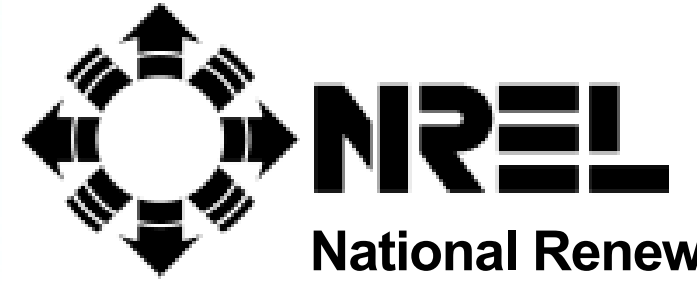

1617 Cole Boulevard

Golden, Colorado 80401-3393

NREL is a U.S. Department of Energy Laboratory

Operated by Midwest Research Institute $\bullet$ Battelle $\bullet$ Bechtel

Contract No. DE-AC36-98-G010337 


\section{NOTICE}

The submitted manuscript has been offered by an employee of the Midwest Research Institute (MRI), a contractor of the US Government under Contract No. DE-AC36-99G010337. Accordingly, the US Government and MRI retain a nonexclusive royalty-free license to publish or reproduce the published form of this contribution, or allow others to do so, for US Government purposes.

This report was prepared as an account of work sponsored by an agency of the United States government. Neither the United States government nor any agency thereof, nor any of their employees, makes any warranty, express or implied, or assumes any legal liability or responsibility for the accuracy, completeness, or usefulness of any information, apparatus, product, or process disclosed, or represents that its use would not infringe privately owned rights. Reference herein to any specific commercial product, process, or service by trade name, trademark, manufacturer, or otherwise does not necessarily constitute or imply its endorsement, recommendation, or favoring by the United States government or any agency thereof. The views and opinions of authors expressed herein do not necessarily state or reflect those of the United States government or any agency thereof.

Available electronically at http://www.doe.gov/bridge

Available for a processing fee to U.S. Department of Energy and its contractors, in paper, from:

U.S. Department of Energy

Office of Scientific and Technical Information

P.O. Box 62

Oak Ridge, TN 37831-0062

phone: 865.576 .8401

fax: 865.576.5728

email: reports@adonis.osti.gov

Available for sale to the public, in paper, from:

U.S. Department of Commerce

National Technical Information Service

5285 Port Royal Road

Springfield, VA 22161

phone: 800.553 .6847

fax: 703.605.6900

email: orders@ntis.fedworld.gov

online ordering: http://www.ntis.gov/ordering.htm

Printed on paper containing at least $50 \%$ wastepaper, including $20 \%$ postconsumer waste 


\title{
OPTICAL MODELING OF a-Si SOLAR CELLS
}

\author{
BHUSHAN SOPORI*, JAMAL MADJDPOUR*, YI ZHANG*, WEI CHEN*, \\ SUBHENDU GUHA**, JEFF YANG**, ARINDAM BANERJEE**, STEVEN HEGEDUS*** \\ *National Renewable Energy Laboratory, Golden, CO \\ **United Solar Systems Corp., Troy, MI \\ ***Institute of Energy conversion, Newark, DE
}

\section{ABSTRACT}

We describe applications of PV Optics to analyze the behavior of a metallic back-reflector on an a-Si solar cell. The calculated results from PV Optics agree well with the measured data on solar cells. Several unexpected results obtained from these calculations are qualitatively explained.

\section{INTRODUCTION}

Modern high-efficiency amorphous-Si solar cells use fairly complex optical designs. Typically, these cells may have three junctions and as many as 12 layers of metal, dielectric, and semiconductor materials. Furthermore, they use many design features that are very difficult or even impossible to handle by a simple optical analysis. These features include (i) nonplanar interfaces, (ii) a combination of thick and thin layers, (iii) multiple semiconductors of different optical properties, and (iv) dielectric and metal coatings. More mature numerical analysis tools are needed to deal with the complicated optical design and analyses of these cells and modules. We have recently developed an optical software package, $P V$ Optics that can handle many aspects of cell and module design. This paper describes some results of applying PV Optics to the design of a-Si solar cells. The intent of this short paper is not to deal with a comprehensive cell design, but to identify features of the software that can address unique cell-design issues.

\section{BRIEF DESCRIPTION OF PV OPTICS}

PV Optics is a software package developed for the design of thick as well as thin multilayer solar cells and modules. It can handle multilayer structures of highly absorbing semiconductor and metallic layers with planar and nonplanar interfaces. It uses combined features of ray and wave optics selected by coherence criteria. This package outputs a variety of data in a form that can be easily used by a design engineer. These data include plots of reflectance, transmittance, absorbed photon flux and its distribution within each layer, and the Maximum Achievable Current Density (MACD) from each active layer. MACD is the value of the photocurrent if each absorbed photon produces an electron-hole pair and all of the generated carriers are collected. Further description of the package is given elsewhere [1,2]. Here we will primarily use MACD as a measure of the cell performance.

\section{RESULTS AND DISCUSSION}

We first describe some capabilities of PV Optics that make it well suited for a-Si solar cell analysis and design. We show that if the optical parameters of a cell are known, the theory can yield results that are in good agreement with the experimental data. Next, we discuss examples related to back-reflector design, and arrive at some physical insight into the back-reflector optics. The examples described here are not meant to be exhaustive, but are selected to illustrate mechanisms that must be considered in analysis of back-reflector design of thin devices.

\section{Comparison of theory and experiment}

Previous publications have shown that for thick, wafer-based Si solar cells, the calculated results from $P V$ Optics agree very well with the experimental results [2,3]. Here we will first illustrate a 
similar correlation between the theory and the experiment for a thin, single-junction cell consisting of a-Si layers on a metal substrate. To accomplish this, single-junction, $\mathrm{p} / \mathrm{i} / \mathrm{n}$ devices were fabricated at United Solar with controlled parameters and thicknesses. One of the objectives of our study is to compare light trapping properties of a planar versus a textured metal interface; these interface configurations were included in the fabricated cells.

Figure 1 illustrates the structure of the cells, the nature of interfaces, and the thickness of each layer. In Figure 1a, all layers have a conformal texture on the metal substrate, while in Figure 1b the cell has a planar metal-buffer interface. All physical and optical parameters, such as thickness of each layer, texture shape and height (h), and refractive indices and extinction coefficients, were measured and input into the PV Optics. The calculated MACD and the measured values of $\mathrm{J}_{\mathrm{ph}}$ are given in Table 1. A good agreement between the theory and the experiment is seen. It may be noted that, because the MACD does not include electronic losses due to carrier recombination, it is expected, in general, to be somewhat higher than the actual value of $\mathrm{J}_{\mathrm{ph}}$. From Table 1 we also see that, in this cell structure, the planar buffer interface results in a lower current than when the interface is textured.

Table 1: A Comparison of Theoretical and Experimental Values of Photocurrent from Cells Whose Structures are Shown in Figure 1.

\begin{tabular}{|l|l|l|l|l|}
\hline $\begin{array}{l}\text { Substrate } \\
(+ \text { metal })\end{array}$ & $\begin{array}{l}\text { Buffer }(\mathrm{ZnO}) / \text { metal } \\
\text { interface }\end{array}$ & $\begin{array}{l}\text { Cell config. } \\
(\text { Planar or textured) }\end{array}$ & $\begin{array}{l}\text { Calculated MACD } \\
\left(\mathrm{mA} / \mathrm{cm}^{2}\right)\end{array}$ & $\begin{array}{l}\text { Jph, United } \\
\text { Solar-Cell } \\
\left(\mathrm{mA} / \mathrm{cm}^{2}\right)\end{array}$ \\
\hline stainless steel & N/A & Planar (Fig. 1b) & 12.56 & 12.7 \\
\hline Ag/ stainless steel & Planar & $\mathrm{h}_{\text {tex. }}=0.1 \mu \mathrm{m}$ (Fig. 1a) & 17.05 & 15.7 \\
\hline $\mathrm{Ag} /$ stainless steel & Textured & $\mathrm{h}_{\text {tex }}=0.2 \mu \mathrm{m}$ (Fig. 1a) & 18.0 & 16.8 \\
\hline
\end{tabular}

(a)

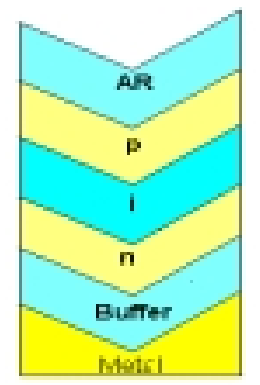

(b)



Figure 1. The structures of the cells fabricated for comparison with theory.

Layer thicknesses

AR: ITO/0.069 $\mu \mathrm{m}$; p-layer: $0.0243 \mu \mathrm{m}$; i-layer: $0.2795 \mu \mathrm{m}$; n-layer: $0.0333 \mu \mathrm{m}$;

buffer: $0.5 \mu \mathrm{m}$

\section{The dependence of $J_{\text {ph }}$ on buffer thickness}

Although some excellent work has been done toward optimizing the back-reflector leading to fabrication of record efficiency a-Si solar cells, much of this is based on empirical analysis using arguments from conventional optics $[4,5,6]$. However, because a back reflector involves nonplanar interfaces and highly absorbing layers, the conventional concepts must be used with care. As an example, we consider the concepts involved in qualitatively predicting the effect of the buffer layer thickness on the MACD of the cell illustrated in Figure1a (with textured buffermetal interface). From the conventional optical considerations, the effect of a non-absorbing buffer layer may be viewed in two ways. Firstly, from mirror technology it is known that the reflectance from an air-metal interface can be enhanced by depositing a thin layer of a low-index dielectric. By a similar argument, the insertion of the buffer layer between a-Si and the back metal is expected to increase the cell current by lowering the metal loss. Secondly, because the buffer layer has significantly lower refractive index compared to a-Si, one normally expects that light emerging from a high index medium will experience total reflection when the incidence 
angle at the interface exceeds the critical angle. Thus, from both considerations, it is expected that for a loss-less buffer material (a) as the buffer thickness increases, the cell current should increase, and (b) cell current will also increase if the refractive index of the buffer is reduced.

Now we consider the calculated results from PV Optics. Figure 2a shows the calculated MACD as a function of buffer thickness for the cell illustrated in the Figure 1a, with $\mathrm{ZnO}$ as the buffer. This figure shows an unexpected dependence of the MACD on the buffer thickness; the MACD value first decreases to a minimum value of $17.2 \mathrm{~mA} / \mathrm{cm}^{2}$, and then increases again toward the value of $18 \mathrm{~mA} / \mathrm{cm}^{2}$. To investigate this further, let us also examine the effect of replacing the $\mathrm{ZnO}$ buffer layer with $\mathrm{MgF}_{2}$ whose refractive index is lower than that of $\mathrm{ZnO}$. Figure $2 \mathrm{~b}$ shows the dependence of MACD on the thickness of $\mathrm{MgF}_{2}$ as a buffer. We see that the MACD is lower with $\mathrm{MgF}_{2}$ compared to $\mathrm{ZnO}$ - again, this is not expected from the conventional wisdom.

(a)

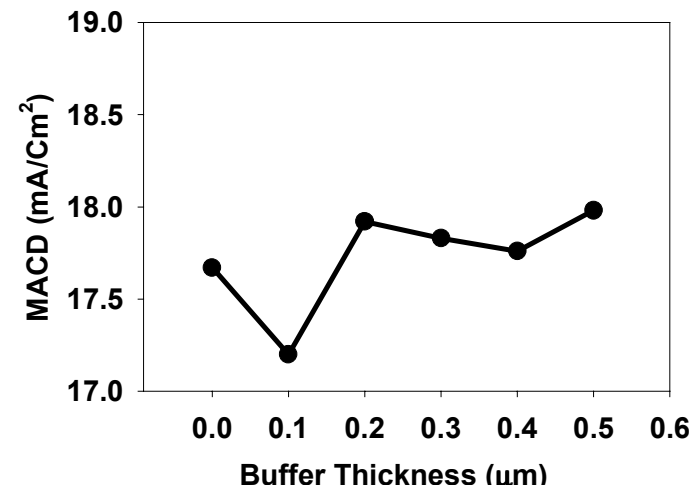

(b)

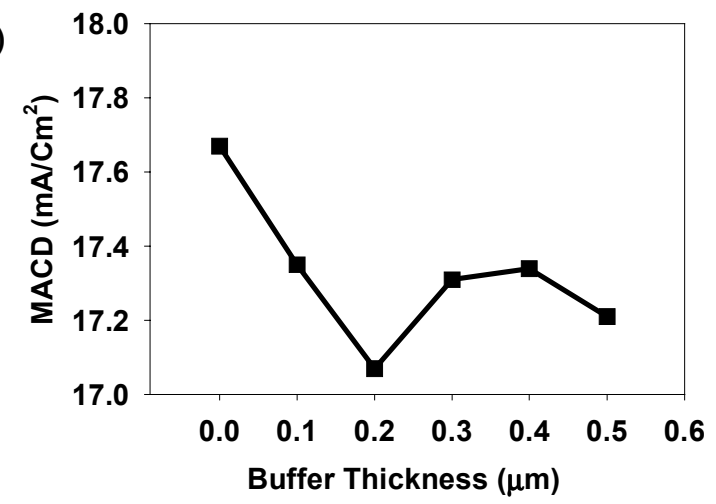

Figure 2. Calculated MACD for the cell shown in Figure 1, as a function of buffer thickness (a) buffer $=\mathrm{ZnO}$, and (b) buffer $=\mathrm{MgF}_{2}$.

To understand the behavior of MACD as a function of the buffer layer thickness, it is fruitful to consider a simpler case of a single a-Si layer on a metal substrate with a $\mathrm{ZnO}$-buffer layer, as shown in Figure 3a. The cell has a planar front and a textured back interface as shown in figure. The a-Si layer has a thickness of $0.4 \mu \mathrm{m}$ and a texture height of $0.3 \mu \mathrm{m}$, respectively. Figure $3 \mathrm{~b}$ shows the plot of calculated MACD vs. buffer thickness, and for two cases of metal-Ag and Al. We see that, for the Ag back reflector, the MACD value decreases with the buffer thickness, whereas for an $\mathrm{Al}$ back reflector, the MACD is lower for all thicknesses of the buffer layer and shows a peak at $0.1 \mu \mathrm{m}$ buffer thickness. A detailed understanding of this behavior is beyond the

(a)

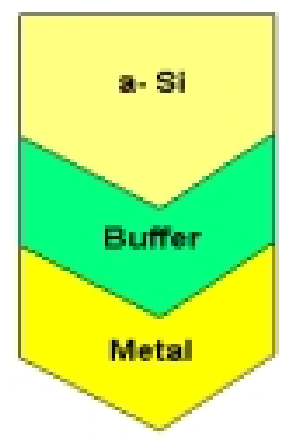

(b)

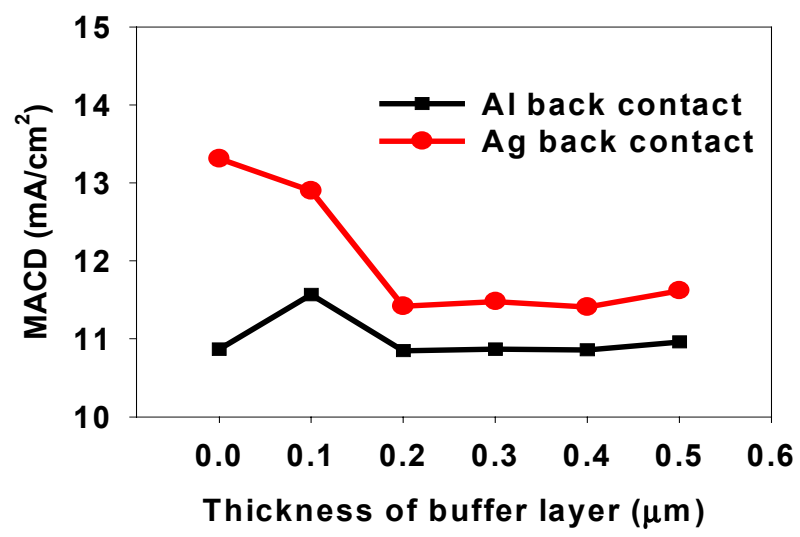

Figure 3. (a) The structure of the cell considered in Figure 3b. (b) Plot of MACD as a function of buffer $(\mathrm{ZnO})$ thickness. 
scope of this paper, but one can qualitatively visualize it by considering behavior of light at the a-Si-buffer and buffer-Ag interfaces. Figure 4 is drawn to help recognizing the following:

(a)

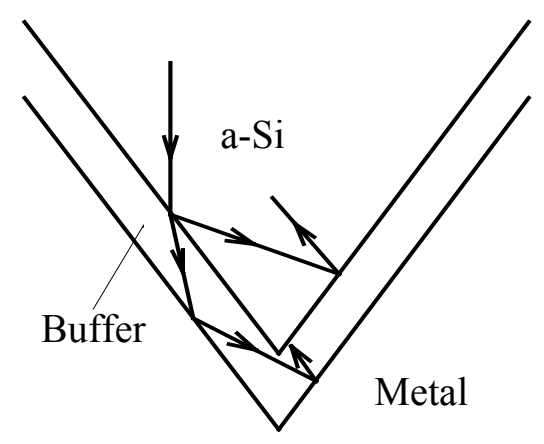

(b)



Figure 4. (a) Illustration of optical path at a textured back interface. (b) Calculated reflectance at the a-Si/ZnO interface.

1. Light reaching the backside of the cell will be incident on the a-Si-buffer interface at a large angle, and will experience reflection and transmission. If the buffer thickness is zero, the reflection coefficient at the a-Si-Ag interface is $\sim 0.97$, and the beam will experience two reflections from the texture before propagating back to the a-Si-air interface (see Figure 4a). Thus, a beam after two reflections at this interface will have a net reflectance of about 0.94 .

2. When the buffer layer is present and the angle of incidence exceeds critical angle, it is important to recognize that the reflectance at the a-Si-buffer interface is not unity. Figure $4 \mathrm{~b}$ shows the reflectance at a-Si-ZnO interface as a function of the incident angle. Also shown is the reflection coefficient for a nonabsorbing a-Si (i.e., where $\mathrm{k}=0$ ). It is seen that the absorption of a-Si alters its total-internal-reflection behavior; and the reflectance is significantly less than unity, even when the angle of incidence exceeds the critical angle. Thus, a part of the light is transmitted into the buffer, and the absorption in a-Si is also reduced. This is true only for one propagation path of the beam.

3. The light transmitted to the metal interface also has a high reflection coefficient, but the effective reflectance at the a-Si-buffer is lower.

4. One can track the effective reflectance as a function of buffer thickness to qualitatively explain the results of Figure 3. These results will be discussed in detail elsewhere. It should be pointed out for a more lossy metal, such as Al, the results could be quite different from that of Ag.

This behavior of the cell structure in Figure 3a can be contrasted with a similar cell when all the interfaces are made planar. Figure 5 shows MACD as a function of buffer thickness for a planar, 0.4- $\mu \mathrm{m}$-thick, a-Si cell. The calculations were performed for $\mathrm{ZnO}$ and $\mathrm{MgF}_{2}$ as the buffer, and $\mathrm{Ag}$ and $\mathrm{Al}$ as the back-reflector layers. It is seen that inserting a buffer layer of a low index material can reduce the metallic loss and hence increase the MACD. Furthermore, the buffer with the lower index offers more effective "isolation" from the metallic layer. The figure also shows the interference effect associated with the buffer layer, manifested as a modulation of MACD with thickness. These results show that the analysis and the design of a textured or rough cell is quite involved and requires more detailed considerations of the optical phenomena. 




Figure 5. Calculated MACD's of a planar, single-layer cell as functions of buffer thickness on different buffers and back contacts

\section{Dependence on the texture parameters}

Table 2 lists results of analyses showing the effect of texture height on the MACD. These calculations are performed for the structures shown in Figure 1. We have used two different values of texture height $-\mathrm{h}=0.2 \mu \mathrm{m}$, and $0.1 \mu \mathrm{m}$. The ITO layer is an antireflection coating that results in an increase in the $\mathrm{J}_{\mathrm{ph}}$. Interestingly, it is seen that an increase in the texture height has a slightly negative effect on MACD - which is again unexpected. Other calculations (not described here) indicate that the texture angle has a stronger effect on the MACD as compared to the texture height.

Table 2. Effect of light-trapping parameters on the photo-currents in single-junction devices

\begin{tabular}{|l|l|l|l|l|}
\hline $\begin{array}{l}\text { Substrate } \\
(+ \text { metal })\end{array}$ & $\begin{array}{l}\text { Buffer }(\mathrm{ZnO}) / \mathrm{metal} \\
\text { interface: } \text { planar or } \\
\text { textured }\end{array}$ & Texture height & $\begin{array}{l}\text { Calculated } \mathrm{ph}_{\mathrm{ph}} \\
\left(\mathrm{mA} / \mathrm{cm}^{2}\right)\end{array}$ & $\begin{array}{l}\text { Jph, United } \\
\text { Solar-Cell } \\
\left(\mathrm{mA} / \mathrm{cm}^{2}\right)\end{array}$ \\
\hline $\mathrm{Al} / \mathrm{SS}$ & Planar & $\mathrm{h}=0.1 \mu \mathrm{m}$ & $\begin{array}{l}14.85 \text { (no ITO) } \\
16.26 \text { (with ITO) }\end{array}$ & \\
\hline $\mathrm{Al} / \mathrm{SS}$ & Planar & $\mathrm{h}=0.2 \mu \mathrm{m}$ & $\begin{array}{l}14.77 \text { (no ITO) } \\
16.1 \text { (with ITO) }\end{array}$ & \\
& & $\mathrm{h}=0.1 \mu \mathrm{m}$ & 16.85 (with ITO) & 15.7 \\
\hline $\mathrm{Ag} / \mathrm{SS}$ & Planar & $\mathrm{h}=0.2 \mu \mathrm{m}$ & 16.66 (with ITO) & \\
\hline $\mathrm{Ag} / \mathrm{SS}$ & Planar & $\mathrm{h}=0.1 \mu \mathrm{m}$ & $\begin{array}{l}14.86 \text { (no ITO) } \\
16.44 \text { (with ITO) }\end{array}$ & \\
\hline $\mathrm{Al} / \mathrm{SS}$ & Textured & $\mathrm{h}=0.2 \mu \mathrm{m}$ & $\begin{array}{l}14.8 \text { (no ITO) } \\
16.41 \text { (with ITO) }\end{array}$ & \\
\hline $\mathrm{Al} / \mathrm{SS}$ & Textured & $\mathrm{h}=0.1 \mu \mathrm{m}$ & 17.51 (with ITO) & \\
& & $\mathrm{h}=0.2 \mu \mathrm{m}$ & 17.45 (with ITO) & 16.8 \\
\hline $\mathrm{Ag} / \mathrm{SS}$ & Textured & & & \\
\hline $\mathrm{Ag} / \mathrm{SS}$ & Textured & & & \\
\hline
\end{tabular}

\section{The influence of the bottom layer thickness on a three-junction cell}

In this example, we consider how the thickness of the bottom layer in a three-junction cell will influence the MACD in all three Si layers. The cell structure used in our calculation is shown in Figure $6 \mathrm{~b}$. The thicknesses of the different a-Si layers are: a-Si-T $=0.3 \mu \mathrm{m}, \mathrm{a}-\mathrm{Si}-\mathrm{M}=0.2 \mu \mathrm{m}$, and $\mathrm{a}-\mathrm{Si}-\mathrm{B}=$ variable, corresponding to top, middle, and bottom cells, with bandgaps of 1.8, 1.6, and $1.4 \mathrm{eV}$, respectively. The results are plotted in Figure 6a. As expected, the MACD of the bottom 
layer increases with the increase of its thickness. But the MACD of the top layer actually decreases when the bottom layer becomes thicker. Also plotted is the total current from the cell, which shows an increase with the bottom- layer thickness. The metal used for this example is Al.

(a)

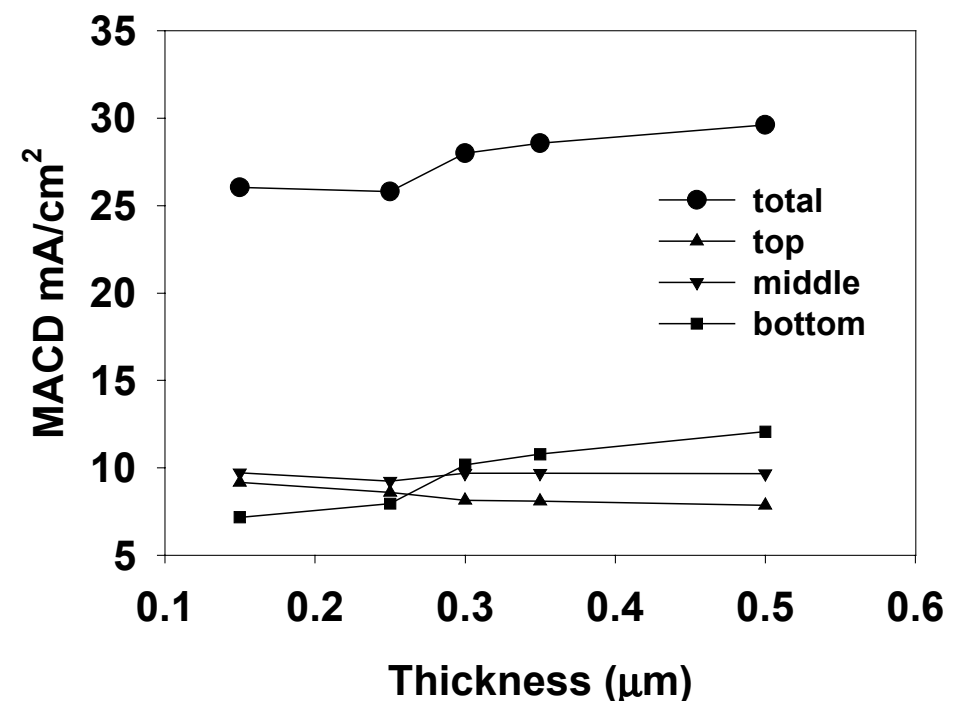

(b)



Figure 6. (a) Calculated MACD of a three-junction cell as a function of the thickness of the bottom layer. (b) The cell structure considered in the calculation.

\section{CONCLUSIONS}

We have pointed out some capabilities of PV Optics in the a-Si cell design to show that it yields results in good agreement with those measured from the a-Si cells. We have also shown that the somewhat-unexpected results from the back-reflector analysis can be understood by considering details of the optical processes. Because these processes are included in the PV Optics, it can serve as a tool not only for cell design, but also to develop an insight into the loss mechanisms.

\section{ACKNOWLEDGEMENT}

This work was supported by US Department of Energy under Contract \#DE-AC36-98G010337and by the DOE Center of Excellence for Advanced Materials Processing. The work at United Solar was supported in part by NREL under subcontract \# ZAK-8-17619-09.

\section{REFERENCES}

[1] B. L. Sopori, Laser Focus, 34, 159 (Feb. 1998).

[2] B. L. Sopori and T. Marshall, Procd. $23^{\text {rd }}$ IEEE Photovoltaic Specialists Conference, 1993 (New York: IEEE).

[3] B. L. Sopori, J. Madjdpour, B. von Roedern, W. Chen, and S. S. Hegedus, MRS Symp. Proc. 467, 777 (1997).

[4] A. Banerjee and S. Guha, J. Appl. Phys., 69 (2), 1991.

[5] S. S. Hegedus and X. Deng, Proc. $25^{\text {th }}$ IEEE PVSC, Washington DC, 1061(1996).

[6] A. Banerjee, J. Yang, K. Hoffman, and S. Guha, Appl. Phys. Lett., 65, 472(1994). 


\section{REPORT DOCUMENTATION PAGE}

Public reporting burden for this collection of information is estimated to average 1 hour per response, including the time for reviewing instructions, searching existing data sources, gathering and maintaining the data needed, and completing and reviewing the collection of information. Send comments regarding this burden

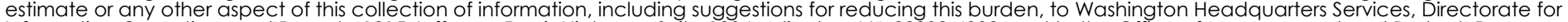

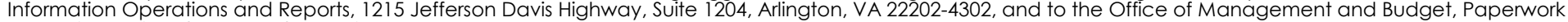
Reduction Project (0704-0188), Washington, DC 20503.

\begin{tabular}{|l|l|l|l|}
\hline 1. AGENCY USE ONLY (Leave blank) & $\begin{array}{l}\text { 2. REPORT DATE } \\
\text { November } 1999\end{array}$ & $\begin{array}{l}\text { 3. REPORT TYPE AND DATES COVERED } \\
\text { conference paper }\end{array}$ \\
\hline 4. TITLE AND SUBTITLE &
\end{tabular}

Optical Modeling of a-Si Solar Cells

6. $\operatorname{AUTHOR}(S)$

B. Sopori

5. FUNDING NUMBERS

7. PERFORMING ORGANIZATION NAME(S) AND ADDRESS(ES)

TA: PV902503

7. PERFORMING ORGANIZAIONNAME(SI ANDADDRESSIESI

9. SPONSORING/MONITORING AGENCY NAME(S) AND ADDRESS(ES)

National Renewable Energy Laboratory

1617 Cole Blvd.

Golden, CO 80401-3393

8. PERFORMING ORGANIZATION REPORT NUMBER

11. SUPPLEMENTARY NOTES

12a. DISTRIBUTION/AVAILABILITY STATEMENT

National Technical Information Service

12b. DISTRIBUTION CODE

U.S. Department of Commerce

5285 Port Royal Road

Springfield, VA 22161

13. ABSTRACT (Maximum 200 words)

We describe applications of $P V$ Optics to analyze the behavior of a metallic back-reflector on an a-Si solar cell. The calculated results from $P V$ Optics agree well with the measured data on solar cells. Several unexpected results obtained from these calculations are qualitatively explained.

\begin{tabular}{|l|l} 
14. SUBJECT TERMS & 15. NUMBER OF PAGES
\end{tabular} photovoltaics ; optical modeling ; amorphous silicon ; solar cells

17. SECURITY CLASSIFICATION OF REPORT Unclassified
18. SECURITY CLASSIFICATION OF THIS PAGE Unclassified
19. SECURITY CLASSIFICATION OF ABSTRACT Unclassified
10. SPONSORING/MONITORING AGENCY REPORT NUMBER

CP-520-25783

16. PRICE CODE

20. LIMITATION OF ABSTRACT

UL

Standard Form 298 (Rev. 2-89) Prescribed by ANSI Std. Z39-18 